\title{
General characteristics of airborne pollen in MonteVideo CITY, URUGUAY
}

\author{
LETICIA TEJERA ${ }^{1}$, ÁNGELES BERI ${ }^{1}$ and XIMENA MARTÍNEZ BLANCO ${ }^{1}$
}

\begin{abstract}
Resumen: Características generales del polen aéreo en Montevideo, Uruguay. Este trabajo analiza las variaciones diarias y estacionales y la influencia de las condiciones meteorológicas en las concentraciones de polen en el período de junio de 2011 a mayo de 2014. Fueron identificados noventa y tres taxones polínicos, correspondientes a 49 tipos arbóreos y a 44 tipos polínicos herbáceos. Los tipos polínicos más importantes fueron Poaceae, Platanus, Cupressaceae/Taxaceae, Eupatorieae type, Celtis, Urticaceae, Myrtaceae, Casuarina, Amaranthaceae, Cyperaceae, Fraxinus, Arecaceae, Ricinus communis, Moraceae, Myrsine, Ambrosia, Quercus y Pinaceae. Se registró polen todos los días del año, pero el período de polinización principal se registró desde agosto a abril. Se observaron diferencias interanuales en los índices polínicos, en las fechas y concentraciones diarias máximas, así como en las concentraciones mensuales acumuladas. La temperatura media, la humedad relativa del aire y la dirección y velocidad del viento fueron las variables meteorológicas con mayor influencia sobre el polen aéreo. Las concentraciones polínicas excedieron los umbrales considerados como moderados o altos un promedio de 182 días al año.
\end{abstract}

Palabras clave: Polen aéreo, meteorología, umbrales de concentración, viento, Montevideo, Uruguay.

Summary: This paper analyses daily and seasonal variations on pollen concentrations and the influence of meteorological conditions on the airborne pollen from June 2011 to May 2014. Data is also compared with results from a previous pollen survey from 2000-2001. Ninety-three taxa were identified, belonging to 49 trees and shrub taxa and 44 herbaceous taxa. The most important pollen sources were Poaceae, Platanus, Cupressaceae/Taxaceae, Eupatorieae type, Celtis, Urticaceae, Myrtaceae, Casuarina, Amaranthaceae, Cyperaceae, Fraxinus, Arecaceae, Ricinus communis, Moraceae, Myrsine, Ambrosia, Quercus, and Pinaceae. Pollen was recorded all year round but the main pollen season was from August to April. Inter-annual differences were observed on pollen indexes, dates and values of daily peak concentrations and monthly accumulated concentrations. Temperature, relative air humidity and wind speed and direction seem to be the most influential meteorological variables on pollen concentrations. The number of days that pollen concentrations are above moderate and high thresholds levels is estimated and woody and non-woody pollen concentrations would be above moderate levels on average 182 days per year.

Key words: Airborne pollen, meteorology, threshold levels, wind, Montevideo, Uruguay.

\section{INTRODUCTION}

Airborne pollen is a common component of atmospheric aerosols and knowing its content in the atmosphere has ecological, agronomic, climatic and clear clinical interests. In particular, pollen allergy has a great impact on public health due to its high prevalence and associated costs.

\footnotetext{
${ }^{1}$ Laboratorio de Palinología, Facultad de Ciencias, Iguá 4225, Montevideo 11400, Uruguay.

* Corresponding author: lete@fcien.edu.uy
}

Allergic diseases like asthma and rhinitis can affect up to $30 \%$ of population in industrialized countries (Asher et al., 2006) and its prevalence seems to be on the increase (D'Amato et al., 2007). Therefore, for allergic patients and allergists it is relevant to know the pollen types present in a particular area at a particular time of the year and the concentrations these taxa achieve (Gentile et al., 2013). Moreover, during this globalization era this information is also relevant for allergic people travelling around the world. Furthermore, long-term airborne pollen records may provide information about plant responses to climate 
change (Ziello et al.,, 2012; Frei \& Gassner, 2007) and its impact on the allergic population (Cecchi et al., 2010). Pollen counts, usually expressed as pollen grains $\mathrm{m}^{-3}$, are still frequently communicated to the population as pollen levels that correspond to different concentration ranges usually based on percentile values, not on health effects (AAAAI 2016). Despite several studies have related pollen concentrations with the development of allergic symptoms (e.g. Breton et al., 2006; Fuhrman et al., 2007), threshold values vary among studies due to several factors and concentration levels for sensitization remain unknown (de Weger et al., 2013).

The aerobiological process includes the production, liberation, transport and impact of pollen grains, fungal spores and other particles (Gregory, 1973). Several meteorological and ecological factors affect this process at different spatial and temporal scales, days to years for pollen preconditioning and impact, minutes to weeks for transport and seconds to hours for liberation, ascent and deposition (Edmonds, 1979). Meteorological conditions may have different effects on atmospheric pollen values, affecting positively or negatively different parts of the aerobiological pathway. Temperature and relative humidity affect anthers formation and dehiscence, thus influencing the amount of pollen produced and liberated (Spieksma et al., 1989). Wind speed favors pollen shedding from anthers and pollen dispersion (Damialis et al., 2005) but has a dilution impact on pollen concentration. Rainfall can also have a positive or negative effect on atmospheric pollen concentrations whether it happens during plant growth, when it has a positive influence on plant physiology, increasing pollen production (Recio et al., 2010) or during the pollination period when it has a washout effect on the atmosphere and decreases the pollen content (Pérez et al., 2009).

Airborne pollen monitoring in Uruguay airborne was first done in 2000 for just one year (Tejera \& Beri, 2003; 2005) and restarted in June 2011. In the region monitoring programs have been done in several cities in Argentina such as Mar del Plata (Bianchi, 1992; Latorre, 1997; Latorre \& Caccavari, 2009; Latorre \& Pérez, 1997; Pérez et al., 2001; 2003), Buenos Aires (Noetinger et al., 1994; Nitiu et al., 2003), La Plata (Nitiu, 2006; Nitiu \& Mallo, 2011; Mallo et al., 2011), Bariloche
(Bianchi \& Olabuenaga, 2006) and Bahía Blanca (Murray et al., 2002; 2007; 2008; 2010; 2016). Research programs are ongoing in Caxias do Sul (Lorscheitter et al., 1986; Vergamini et al., 2006) in Brazil and mainly in Santiago de Chile in Chile (Toro et al., 2015). The relative low number of aerobiological studies performed in the region strongly contrast with the very broad range of environmental gradients present in temperate South America (Olson et al., 2001). Therefore, this study would represent a relevant contribution to aerobiological studies in the region.

The aim of the present study is to analyze the main characteristics of atmospheric pollen in Montevideo city in terms of total, non-woody and woody- plants pollen values and assess the influence of meteorological conditions on pollen concentrations from June 2011 to May 2014.

\section{Materials and Methods}

\section{Study area and plant cover}

Montevideo ( $\left.34^{\circ} 56^{\prime} \mathrm{S}-56^{\circ} 09^{\prime} \mathrm{W}\right)$ the capital and most populated city in Uruguay, with about 1.5 million inhabitants, is located on the Río de la Plata estuarine coast (Fig. 1). The climate is temperatesubtropical humid, with rainfalls throughout the year (1098 mm), mean annual temperature of $16.5^{\circ} \mathrm{C}$ and relative humidity of $75 \%$. Rainfalls are basically

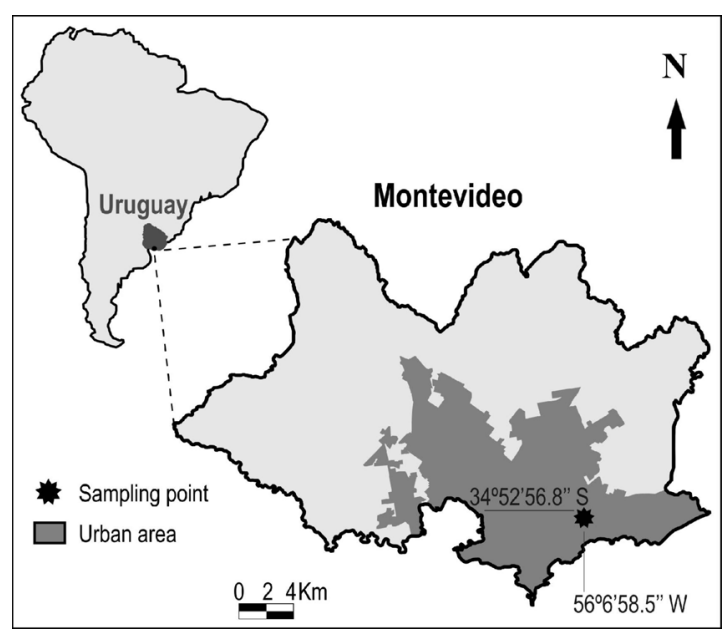

Fig. 1. Location of sampling site at Montevideo, Uruguay. 
controlled by the interaction between the South Atlantic and South Pacific Anticyclones. The region belongs to the Pampa Province, "Uruguayense" District (Cabrera \& Willink, 1973). This "campos" landscape is dominated by grasslands although native woodlands are found along water courses and hills (Soriano, 1992). Montevideo's urban flora is mainly composed of exotic trees and shrub species cultivated for ornamental purposes along streets, avenues, parks and cemeteries over the city. The most abundant trees and shrubs cultivated in public areas of the city are Melia azedarach, Fraxinus pennsylvanica, Eucalyptus globulus, E. camaldulensis and Platanus $x$ acerifolia, other important species are Pinus pinaster, Tipuana tipu, Fraxinus excelsior, F. lanceolata and Acer negundo. Tree species like Nerium oleander, Schinus molle, Jacaranda mimosifolia, Phoenix canariensis, Casuarina cunninghamiana, Populus deltoides, Ligustrum lucidum, Ulmus procera, Eucalyptus globulus, Acer saccharium, Ceiba speciosa, Salix babilonica and S. elegantissima, Arecastrum romanzoffianum, Whashingtonia filifera and $W$. robusta are also very frequent in public spaces (Lombardo 1979, Arcos \& Pose 2008). Herbaceous vegetation is cultivated in parks and private gardens or occurs spontaneously in open areas of the city. The most important herbaceous pollen sources belong to the families Apiaceae, Amaranthaceae, Asteraceae, Poaceae and Urticaceae (Lombardo $1982 ; 1983 ; 1984)$.

\section{Airborne pollen}

Daily pollen concentration was sampled during three years from June 2011 to May 2014. The periods were defined as seasonal years and not to calendar years, and correspond to June 2011- May 2012, June 2012- May 2013 and June 2013- May 2014 sampling periods, respectively. A Rotorod sampler Model 40 (Sampling Technologies Inc.) was used to recover airborne pollen. The sampler was installed on the roof of the Faculty of Science $\left(34^{\circ} 52^{\prime} 56.8^{\prime \prime} \mathrm{S}, 56^{\circ} 06^{\prime} 58.5^{\prime \prime} \mathrm{W}\right)$ in an open area at ca. $12 \mathrm{~m}$ above ground level, complying with requirements for the installation of Rotorod samplers (Brown et al., 1993). Nomenclature follows the recommendations of the International Association of Aerobiology (Galán et al., 2017).

Daily data were obtained according to standard methods (Brown et al., 1993). The rods were collected daily and all pollen grains were counted and analyzed under $400 \mathrm{x}$ magnification Pollen was identified with the aid of the reference collection of the Palynology laboratory and specific bibliography (Bassett et al., 1978; Markgraf \& D'Antoni, 1978; Lewis et al., 1983).

Monthly and total pollen values were estimated by the sum of daily pollen concentration values. Pollen types were grouped according to the growing form of species that produce them in non-woody (NW) and woody (W) pollen types. Data were collected following exactly the same methodology and pollen was identified and counted by the same person as in the present dataset.

Taxa representing at least $0.5 \%$ of total pollen of the period were selected as important taxa and their mean daily pollen concentration and standard deviation were estimated for the whole sampling period.

To look for statistical differences between airborne pollen from all sampled periods and due to the lack of normality of data, Kruskal-Wallis analysis of variance were performed on daily, weekly and monthly values.

Meteorological data used for site characterization corresponds to the historical period 1971-1990. On the other hand, daily data during the studied period were supplied by the Dirección Nacional de Meteorología and correspond to the nearest meteorological station at Carrasco Airport (34 $50^{\prime} \mathrm{S}$, $56^{\circ} 00^{\prime} \mathrm{W}$ ) located $4 \mathrm{~km}$ apart from the sampling point. Kruskal-Wallis analyses of variance were performed on annual means and monthly values in order to assess for differences between years.

To analyze the correlation between woody and non-woody pollen and meteorological data the Spearman Rank non parametric correlation coefficient and multiple linear regression analysis, considering daily values of the whole sampled period, were performed. In order to assess the influence of wind speed and direction on pollen concentrations, bivariate polar plots of mean pollen concentrations by wind direction and speed for the study site and sampling were done on the R package Openair (Carslaw 2015).

Missed sampling days were excluded from all statistics analyses. A total of 14 days of sampling were lost due to a failure of the sampler and saturation of roods with volcanic ash coming from the Puyehue-Cordón Caulle Volcanic Complex 
in southern Chile that erupted on June 4 and September 24, 2011 and remained in the atmosphere for months.

In order to estimate the average number of days pollen concentration was above moderate and high levels, pollen thresholds levels indicated by the AAAAI's National Allergy Bureau (AAAAI 2016) were used. Local pollen threshold levels were estimated for woody and non-woody plants pollen types at Montevideo city considering percentile 50 as the inferior threshold for moderate concentrations and 75 percentile as the inferior threshold for high concentrations. Thresholds were estimated using data of the whole sampled period ( 3 years) and averaged values of the most important woody and non-woody plant pollen types.

\section{Results}

\section{General pattern}

In Montevideo atmosphere a similar total Annual Pollen Integral was obtained for all sampled periods, with the highest value recorded in 2000-2001 (12792 pollen grains $\mathrm{m}^{-3}$ ) and the lowest registered in 2012-2013 (11659 pollen grains $\left.\mathrm{m}^{-3}\right)$ while 20112012 and 2013-2014 12568 and 12193 pollen grains $\mathrm{m}^{-3}$ respectively were recorded. Daily pollen totals also showed a similar pattern along all sampling periods where a main pollen season, representing $97 \%$ of annual totals on average, can be established from August to April (Fig. 2). Moreover, the period of lowest pollen concentration is observed from May to July (Fig. 2), when the minimum pollen values of the period were recorded and monthly totals did not exceed $2 \%$ of total pollen (TP). In general, daily pollen concentrations rise at the end of Julyearly August, reaching higher values in September, November-December and late February-March.

Despite this similar general pattern some differences are appreciated. For instance, the highest peaks were registered in November-December for 2000-2001, March for 2011-2012, AugustSeptember for 2012-2013 and February for 20132014 (Fig. 2).

Non-woody pollen contributed similarly to Annual Pollen Integral during all periods analyzed. However, during 2013-14 period non-woody plants pollen was significantly higher $(p<0.01)$ and explained the higher pollen index registered that year. The highest monthly non-woody totals were reached in different months and December 2000 and February 2013-14 concentrations were significantly higher $(p<0.01)$ (Fig. 3).

Woody pollen showed a similar pattern and roughly similar monthly values all years analyzed, with the highest concentrations recorded in September (Fig. 3). However, statistically significantly higher monthly totals were observed in November 201112, August 2012-13, February and March 2013-14 $(p<0.01)$. In addition, March 2000-01 showed the lowest accumulated concentrations for that month $(p<0.01)$.

Ninety-three pollen taxa were identified at family, genus and, occasionally, species level, where 49 correspond to tree and shrub taxa (woodypollen) and 44 to herbaceous taxa (herbaceouspollen). Although 93 pollen taxa were recorded, only few were registered frequently or in high concentrations. On average, 18 taxa exceeded $0.5 \%$ of total pollen concentration and represent $90 \%$ of total pollen. Figure 4 shows the variation in daily pollen concentrations from year to year. Poaceae was the main and most important contributor to the airborne pollen, accounting for $45.7 \%$ of $\mathrm{TP}$ (Total Pollen) in $2000-2001,47 \%$ of TP in 2013 $14,40 \%$ of TP in $2012-13$ and just $32.6 \%$ of TP in 2011-12. Other important taxa, ordered according their first appearance in the year, considering 1 of June as the start of the calendar year, were: Fraxinus, Cupressaceae/Taxaceae, Pinaceae, Moraceae, Platanus, Quercus, Celtis, Myrtaceae, Urticaceae, Amaranthaceae, Ricinus, Cyperaceae, Myrsine, Casuarina, Arecaceae, Ambrosia type and Eupatorieae type. The first peaks on TP registered in June correspond to Cupressaceae (10.5\% TP) and Fraxinus (1.3\% TP) (Fig. 4). The former reached its higher concentration in August while the latter increased its concentration at the end of Auguststart of September together with Pinaceae $(0.5 \%$ $\mathrm{TP})$, Moraceae $(0.6 \%)$, Platanus $(8.5 \% \mathrm{TP})$ and Quercus (1.1\% TP) (Fig. 4). Pollen concentrations of these winter taxa decreased gradually in October and spring while other woody taxa, in particular, Celtis (0.7\% TP) (Fig. 4) but also Salix, Olea and Anacardiaceae showed its highest values in October and November. Myrtaceae pollen grains (2.1\% TP) were recorded almost all year round, reaching moderate concentrations from November to January, with another period of moderate concentrations 
L. Tejera et al. - Airborne pollen in Montevideo city, Uruguay

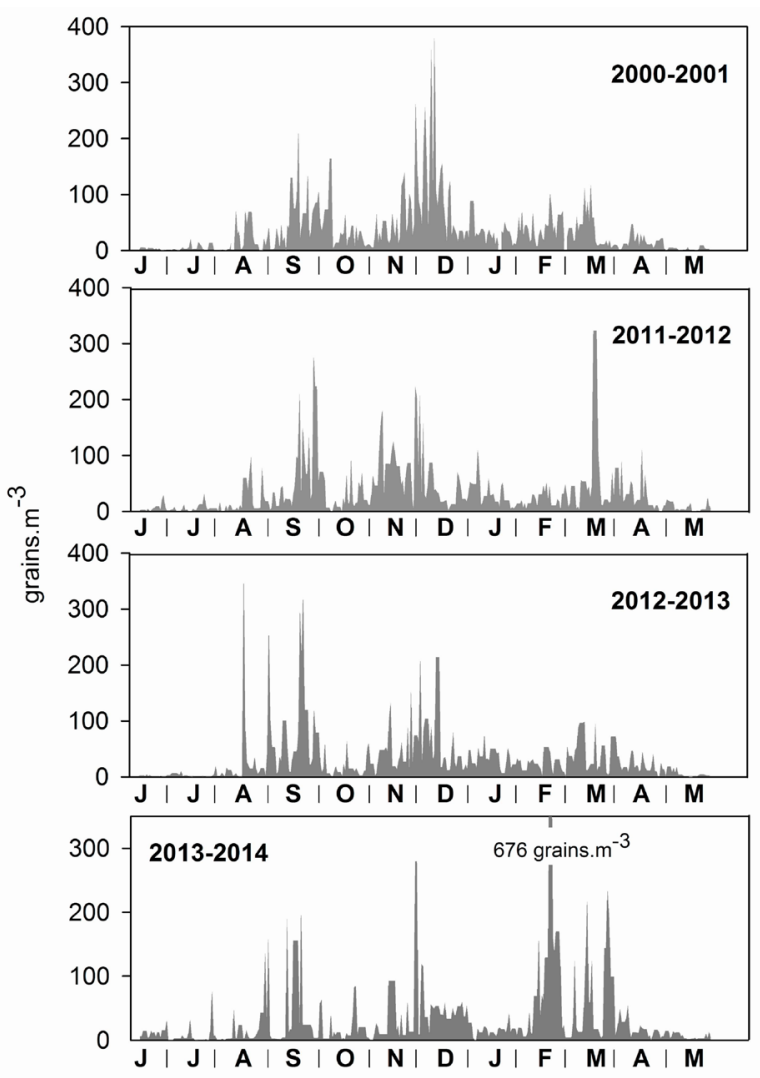

Fig. 2. Daily total pollen concentration per sampling year, expressed as pollen grains $\mathrm{m}^{-3}$

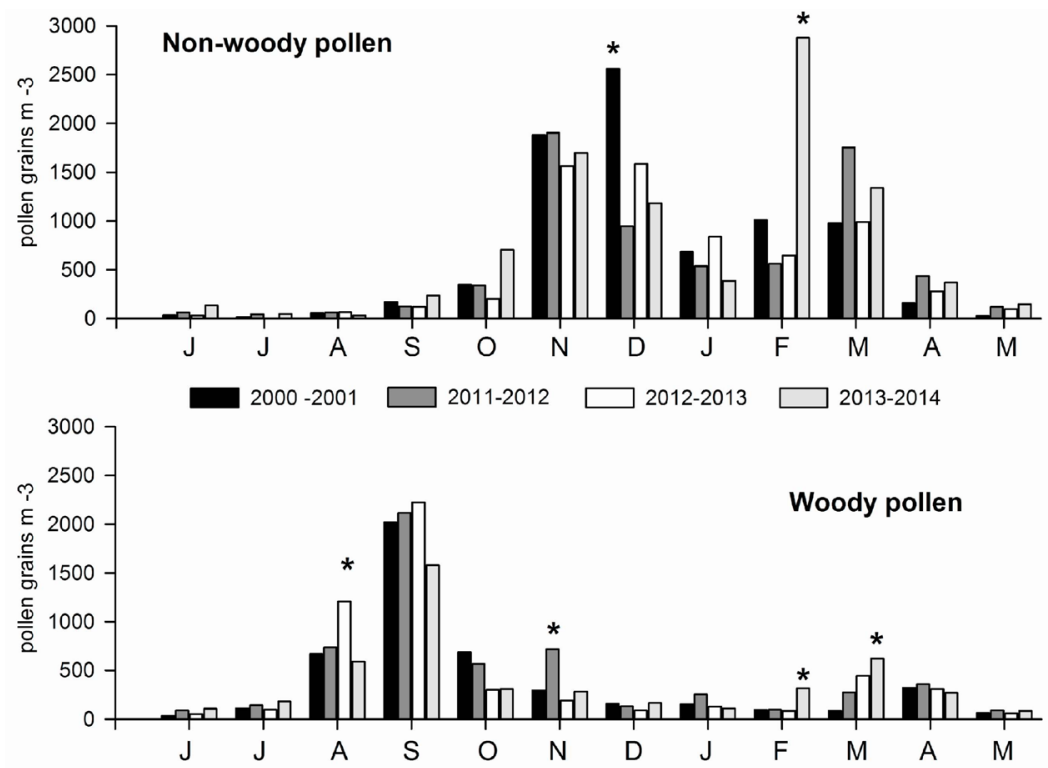

Fig. 3. Accumulated monthly pollen totals of non-woody and woody pollen. * Months with significant differences on pollen concentration. 
Bol. Soc. Argent. Bot. 53 (2) 2018
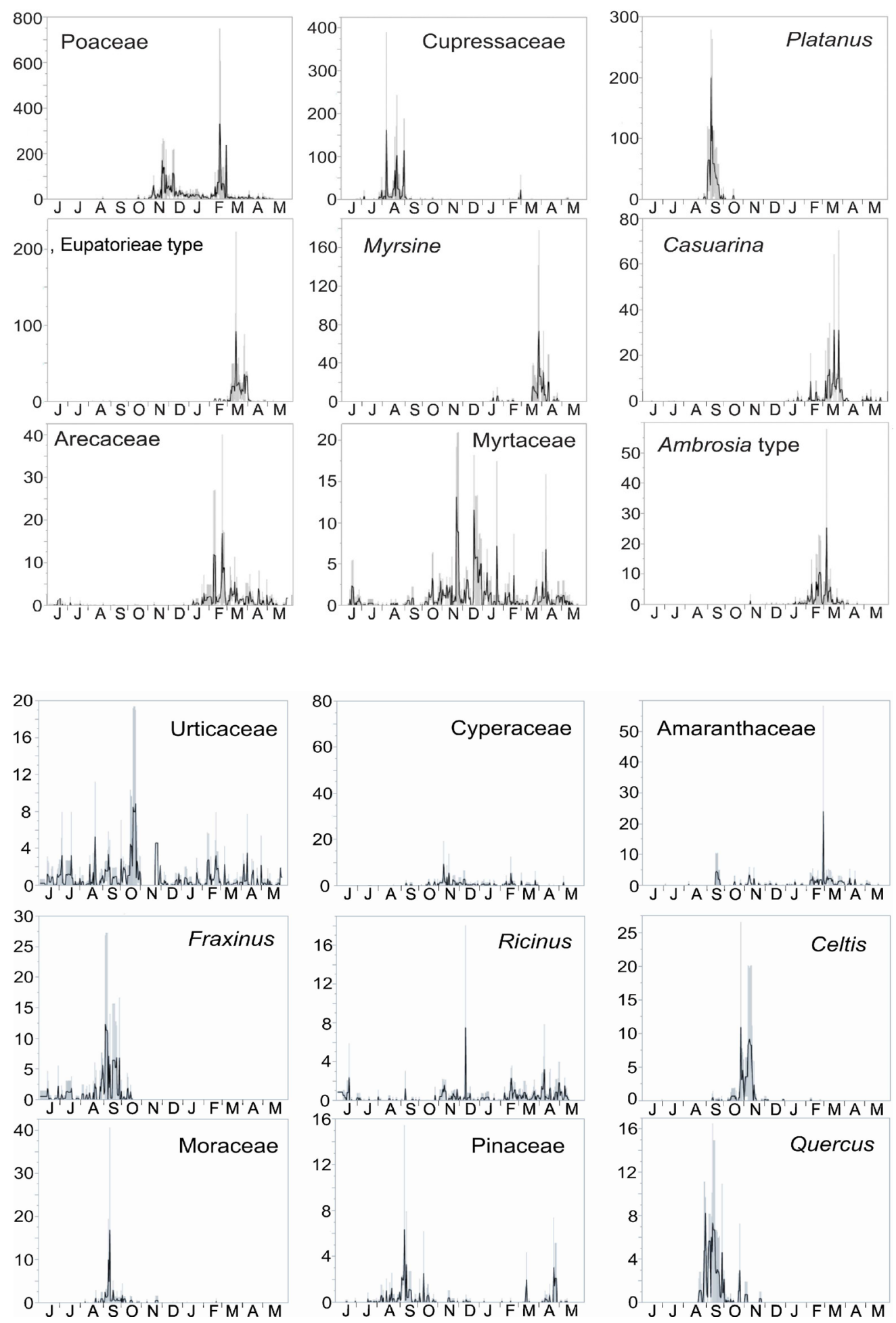

Fig. 4. Average daily counts of the most important pollen types with their corresponding standard deviations for the three year study period, expressed as pollen grains $\mathrm{m}^{-3}$. Note the different scale on the $y$-axis. 
in March (Fig. 4). Non-woody taxa pollen concentrations began to increase in spring. Poaceae and Urticaceae $(1.8 \% \mathrm{TP})$ despite being recorded all year, reached high concentrations in October and November-December, respectively (Fig. 4). In fact, Poaceae concentrations remained in high values until the end of summer, recording another period of very high concentrations in February (Fig. 4). Other nonwoody taxa with very long pollination periods and contributing with moderate or high concentrations in spring and summer were Amaranthaceae (1.5\% TP), Ricinus (0.8\% TP) and Cyperaceae (1.7\% TP) (Fig. 4). In January, summer woody taxa such as Myrsine $3.8 \% \mathrm{TP})$, Casuarina (2.4\% TP) and Arecaceae $(2.3 \% \mathrm{TP})$ began their pollination periods (Fig. 4). Non-woody taxa representing the Asteraceae family, in particular Ambrosia (1.9\% TP) (Fig. 4), also contribute to the airborne pollen recorded on January. Total pollen concentrations remained slightly lower during February and increased again in March, mainly due to high concentrations of Eupatorieae type (5.3\% TP), Myrsine and Casuarina (Fig. 4). Some taxa exhibited little inter-annual variation, like Platanus and Myrtaceae, but in general considerable differences were observed, for instance, in the value and dates of peak concentrations (Fig. 4).

In general, considering the pollen thresholds levels indicated by the AAAAI's National Allergy Bureau (AAAAI 2016), pollen concentrations were above moderate levels an average of 74 days for woody pollen and 265 days for non-woody taxa (Table 1, Fig.2). However, if thresholds are established using Montevideo percentile values (Table 1), woody and non-woody pollen concentrations would be above moderate levels (above percentile 50) an average of 182 days per year. Although, non-woody pollen concentrations exceeded high levels approximately the same days per year independently of the threshold value used. On the other hand, the high concentration threshold estimated in Montevideo (percentile 75) had a much lower value (12 pollen grains $\left.\mathrm{m}^{-3}\right)$ than that established by the NAB $(90$ pollen grains $\mathrm{m}^{-3}$ ). Therefore the average number of days above high concentration levels varied according the threshold used (I).

\section{Relationship with meteorological data}

Mean annual temperature values showed some differences between the periods (Fig. 5A). 20002001 annual average mean temperature was $0.88^{\circ} \mathrm{C}$ above historical values mainly due to warmer end of summer and autumn seasons. In addition, except for January, April and September all monthly mean temperatures showed significant differences between the sampled periods analyzed.

As expected, daily total pollen and non-woody pollen values showed a strong positive correlation with mean daily temperatures (Table 2).

Accumulated rainfall values showed some differences between the years considered. In 20002001 and 2013-2014 higher total rainfalls were registered and in particular the summer of these periods showed larger rainfalls (Fig. 5C). Daily accumulated rainfall values showed a very weak correlation with total daily and non-woody pollen, while total and non-woody pollen concentrations were positively correlated with accumulated rainfalls of previous weeks (Table 2).

Table 1. Pollen concentration thresholds according to NAB and estimated for Montevideo.

\begin{tabular}{|c|c|c|c|c|c|}
\hline \multirow{2}{*}{\multicolumn{2}{|c|}{ Threshold }} & \multicolumn{2}{|c|}{ National Allergy Bureau } & \multicolumn{2}{|c|}{ Montevideo } \\
\hline & & non-woody & woody & non-woody & woody \\
\hline \multirow{2}{*}{ Moderate } & concentration $^{1}$ & 5 & 15 & 6 & 4 \\
\hline & days per year ${ }^{2}$ & 265 & 74 & 182 & 182 \\
\hline \multirow{2}{*}{ High } & concentration & 20 & 90 & 23 & 12 \\
\hline & days per year & 97 & 12 & 91 & 88 \\
\hline
\end{tabular}

${ }^{1}$ Concentration as grains. $\mathrm{m}^{-3} .{ }^{2}$ Average number of days per year above threshold levels. 
Bol. Soc. Argent. Bot. 53 (2) 2018
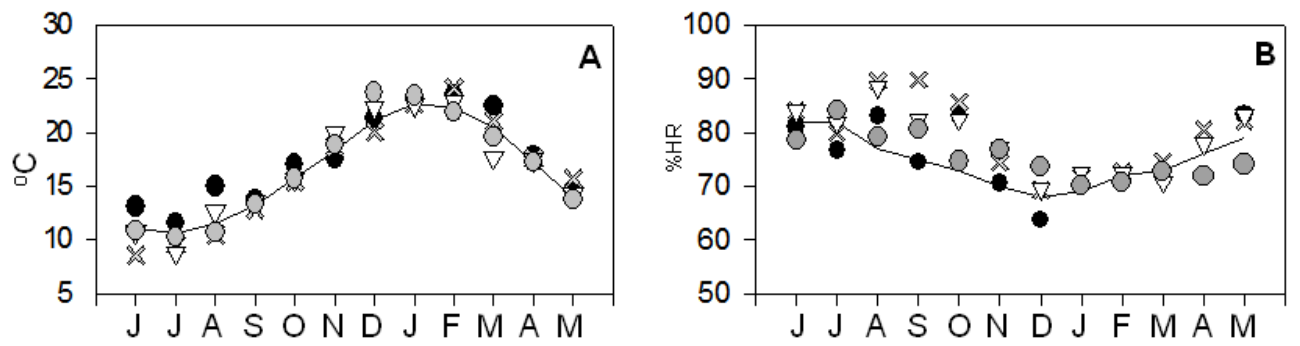

$---1960-1991 \bullet 2000-2001 \times 2011-2012 \nabla 2012-201302013-2014$

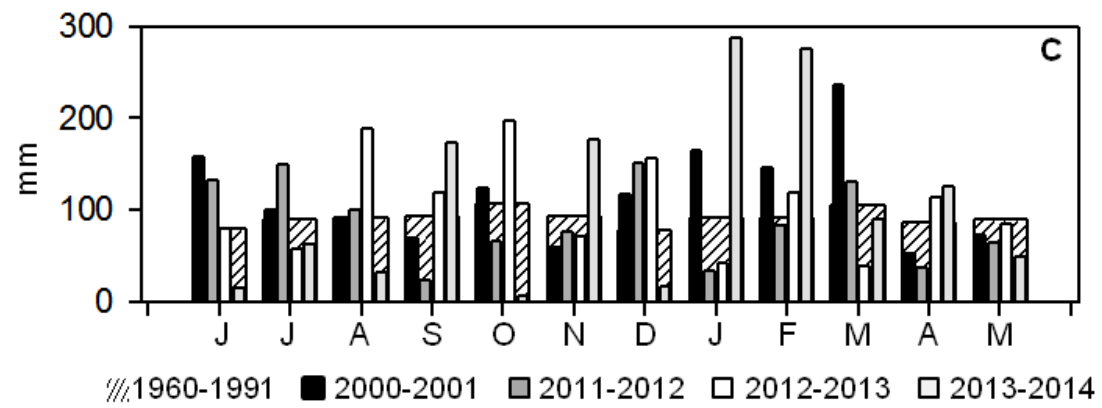

Fig. 5. Meteorological variables of periods analyzed and historical values. A: Average mean monthly temperatures. B: Average relative air humidity. C: Accumulated monthly rainfall.

No significant differences were observed on monthly air relative humidity average values between the years considered and this variable showed a negative correlation with all pollen variables (Table 2).

The prevailing wind directions in Montevideo airport were N, NNE and SE (Fig. 6A) but moderate and high pollen values were also recorded when wind blew from other quadrants (Fig. 6B). Highest mean total pollen values were observed from the NNE at wind speeds above $6 \mathrm{~m} \cdot \mathrm{s}^{-1}$ (Fig. 6B). Nonwoody pollen showed maximum concentrations with winds from the north-east quadrant at speeds above $4 \mathrm{~m} \cdot \mathrm{s}^{-1}$ (Fig. 6C) while woody mean pollen concentrations showed highest values with N-NNE winds above $6 \mathrm{~m} \cdot \mathrm{s}^{-1}$ (Fig. 6D). Moderate pollen

Table 2. Spearman rank correlation coefficients between pollen and meteorological variables.

\begin{tabular}{|c|c|c|c|}
\hline & total & non-woody & woody \\
\hline $\mathrm{T}^{\circ} \mathrm{C}$ & $0.48^{\star *}$ & $0.71^{* *}$ & ns \\
\hline RH & $-0.32^{*}$ & $-0.3^{* *}$ & $-0.12^{*}$ \\
\hline $\mathbf{R f}$ & $-0.14^{\star *}$ & $-0.11^{* *}$ & $-0.09^{*}$ \\
\hline $\mathbf{R f}^{1}$ & $0.21^{*}$ & $0.17^{*}$ & ns \\
\hline ws & $0.14^{* *}$ & $0.18^{* *}$ & $0.08^{\star *}$ \\
\hline wd & $-0.16^{* *}$ & $-0.15^{\star \star}$ & $-0.112^{* *}$ \\
\hline
\end{tabular}

Significance level ${ }^{*} p<0.01,{ }^{* *} p<0.001$. 

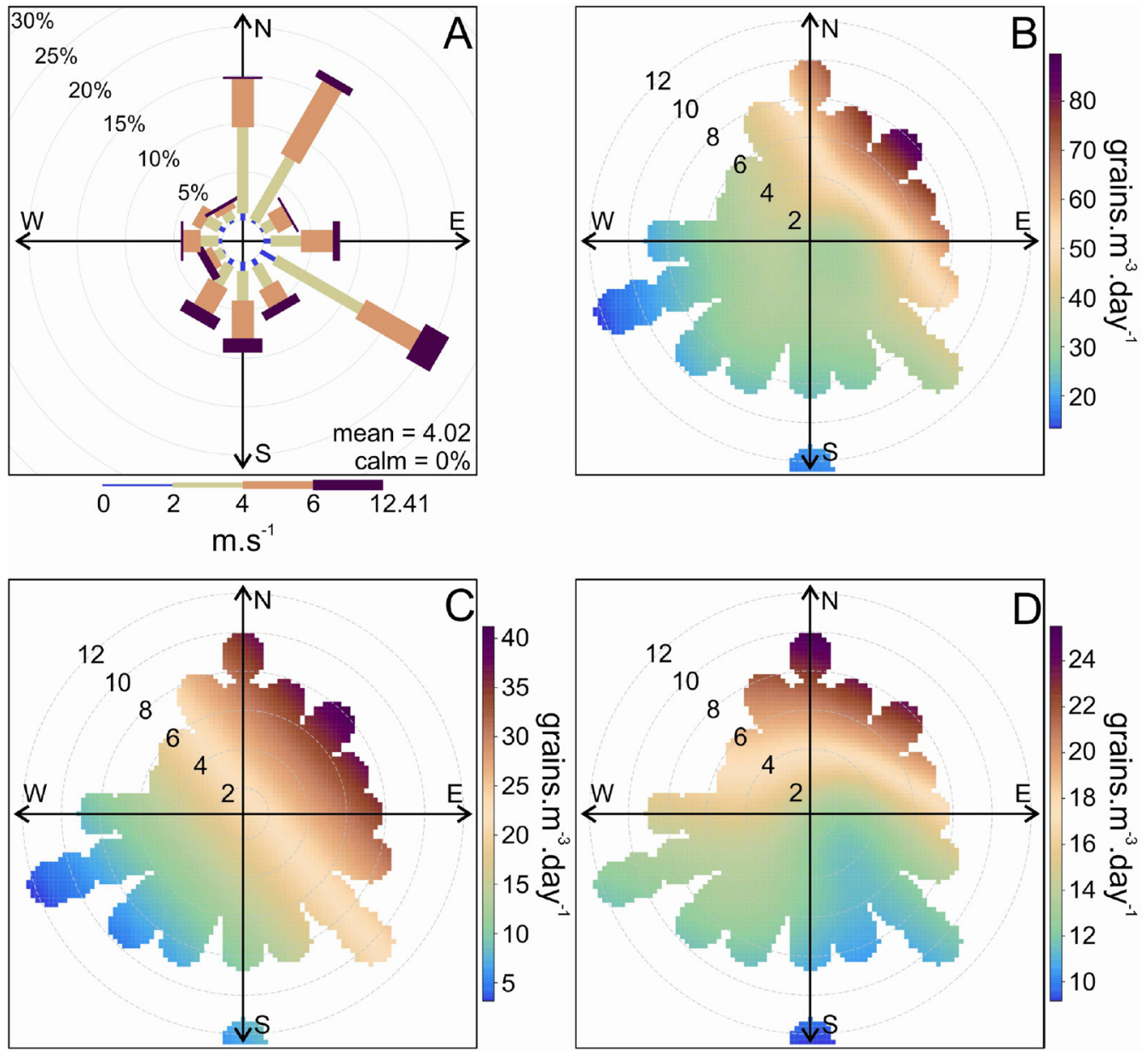

Fig. 6. A: Frequency of wind direction and speed over the study period. Bivariate polar plot of mean pollen concentrations by wind direction and speed for the study site and sampling period (concentric circles represent wind speed in $\mathrm{m} \mathrm{s}^{-1}$ ) B: Total pollen. C: Non-woody pollen. $\mathbf{D}$ : woody pollen.

values were observed at lower wind speeds and covering a wider range of wind directions, from the west-north quadrant for woody-pollen (Fig. 6D) and from the NW to the SE for non-woody pollen (Fig. 6C). Therefore, concerning wind intensity and direction, intensity showed very low but significant influence over pollen concentration values, mainly for total and woody pollen values (Table 2).

Given the high correlation between total daily pollen and non-woody pollen values with mean temperatures and relative humidity, multiple linear regression analysis were performed in order to assess the predictive value of such variables. Average daily temperatures and relative air humidity explained $28 \%$ of total daily pollen concentrations $(\mathrm{r}=0.529, \mathrm{R} 2=0.28, \mathrm{p}<0.001)$ and $51 \%$ of nonwoody pollen concentrations $(r=0.714, \mathrm{R} 2=0.51$, $\mathrm{p}<0.001)$ while daily average temperatures alone explained $47.1 \%$ of all variation.

\section{Discussion}

The annual pollen pattern observed in Montevideo is consistent with seasonal fluctuations described in other cities with temperate climate, where maximum values are recorded in spring and early summer while lower values are registered 
in autumn and winter. The period of major pollen concentration corresponds to the flowering period of most species growing in the city (Lombardo, 1979; 1982; 1983; 1984). In particular, in Mar del Plata and Bahía Blanca maximum concentrations were also recorded from August to April, and relatively low monthly concentrations were observed from January to April (Latorre \& Caccavari, 2009; Murray et al., 2010). However, in other cities such as Buenos Aires (Nitiu et al., 2003) the main emission period ends a month earlier, in March, as it was the case for the period 2000-2001 in Montevideo. The period of minimum pollen values, called residual period in some cases, corresponds to the very end or start of pollen periods of some taxa. Pollen taxa that include several species with very long pollen periods are present all year round e.g. Urticaceae (mainly Parietaria), Myrtaceae, Poaceae and Amaranthaceae.

During the studied period, an average of 12150 pollen grains $\mathrm{m}^{3}$ per year were recorded, similar to total pollen indexes recorded in Caxias (Vergamini et al., 2006) and slightly lower than in Bahía Blanca (Murray et al., 2010) and Santiago de Chile (Rojas $\&$ Roure, 2001). However, Montevideo airborne pollen index is lower than those recorded in other cities of the region such as La Plata (Nitiu, 2006), Buenos Aires (Nitiu et al., 2003), Mar del Plata (Latorre \& Pérez, 1997; Pérez \& Páez, 1998). Even considering the relative higher efficiency of suction samplers (Peel et al., 2014), those indexes are higher than in Montevideo. Furthermore, when overrepresented taxa are excluded from the sum (Latorre \& Caccavari, 2009) total pollen values resemble those of Montevideo. However, in those cities, urban flora is mainly represented by several species of Cupressaceae and Platanus x acerifolia, trees that release vast numbers of pollen grains per pollination season (Tormo et al., 1996; Hidalgo et al., 1999). In Montevideo city some abundant trees present in public areas are enthomophilous and low pollen producers like Melia azedarach, and Tipuana tipu while Eucalyptus globulus and E. camaldulensis trees despite being considered mainly enthomophilous, produce and liberate high amounts of pollen. Nevertheless, anemophilous trees as Fraxinus pennsylvanica, F. lanceolata, Platanus $x$ acerifolia, Pinus pinaster and Cupressus sempervirens are also abundant in public areas in the city (Arcos \& Pose, 2008). It should be considered that these values represent the percentage of trees present in public areas but plants are also cultivated in private gardens and parks.

Non-woody pollen contributed slightly more than woody pollen to Total Pollen in Montevideo atmosphere. Conversely, woody pollen dominates the spectra in other cities of Southern South America like Santiago de Chile (Rojas \& Roure, 2001; Toro et al., 2015), Mar del Plata (Latorre \& Caccavari, 2009), La Plata (Nitiu, 2006) and Caxias (Vergamini et al., 2006). In Montevideo, Poaceae is the most important pollen contributor. Its dominance could be related to the influence of local vegetation on the spectra since the area around the sampling point is an open and grass covered zone. In addition, extra-local (avenues, parks, private gardens) and regional (rural areas) contribution to the spectra could be relevant given that Uruguay belongs to the phytogeographical zone Campos del Río de la Plata (Soriano, 1992) where grasslands are the dominant vegetation. In fact, bivariate analysis of pollen concentration per wind direction and speed support this hypothesis. Despite that moderate concentrations recorded at low wind speed $\left(<2 \mathrm{~m} . \mathrm{s}^{1}\right)$ would indicate local origin, higher pollen concentrations observed at higher wind speed may represent an important contribution from more distant grass pollen sources. In fact, rural areas that are potential grass pollen sources are located in the north-east quadrant at $6 \mathrm{~km}$ from the sampling point (Fig. 1). However, if Poaceae is removed from the analysis, woody pollen acquires more importance in the spectra resembling pollen assemblages of all cities of the region.

No significant differences were observed between Annual Pollen Integrals in Montevideo city. Nevertheless, significant inter-annual differences were noticed in monthly total concentrations in August, October, November, December, February and March. In addition, many important taxa also exhibited variations in dates and peak concentrations from year to year. The higher total pollen observed at the end of October-early November 2011-12 and 2013-14 periods seems to be an early equivalent of the peaks observed in December 2000-2001 and December 2012-13 and seems to be an indication of an early start of the pollen season for non-woody pollen. No major land use changes have occurred around the sampling point or in the city from 2001 that could explain the 


\section{Tejera et al. - Airborne pollen in Montevideo city, Uruguay}

pollen variations observed. Inter-annual differences in airborne pollen concentration is a widely known phenomena and has been explained by a number of events like differences in meteorological conditions (McLauchlan et al., 2011), episodes of long-range transport (Mahura et al., 2007; Cecchi et al., 2007) or inter-annual variation of plant reproductive efforts (Ranta et al., 2008). The main objective the present study was to analyze the main characteristics of atmospheric pollen and therefore more analyses are needed to identify other factors that could explain the inter-annual differences observed. For instance, analyses regarding the individual behavior of pollen types are required.

The diversity of pollen taxa recorded in Montevideo atmosphere represents the floral diversity and the abundance of the anemophilous species growing in the city. The pollination sequence observed was as expected: 1. introduced and native temperate trees flowering at the end of winter with a peak during spring, 2. subtropical trees in summer and autumn, 3. grasses in spring and summer, 4. weeds in summer and early autumn. The most important species recorded in Montevideo's atmosphere are either introduced taxa cultivated for ornamental purposes along public and private spaces or adventitious plants growing in green areas. The predominance of introduced taxa on the pollen spectra seems to be a general characteristic of urban areas where exotic flora is preferred over native taxa. This feature is observed in cities of the region such as Mar del Plata (Latorre \& Pérez, 1997), and Buenos Aires (Nitiu et al., 2003). Despite this, pollen from native taxa such as those from the genus Celtis (mainly Celtis spinosa and Celtis tala), Anacardiaceae (Schinus, Lithraea), Dodonaea viscosa and Myrsine (from Myrsine coriaceae, Myrsine laetevirens, Myrsine parvula) were recorded in the atmosphere. In addition, other native types accounted for low values, representing all together a sort of geographic signature on the atmospheric spectra. Celtis was also recorded in cities of the same biogeographic region such as Mar del Plata (Latorre \& Pérez, 1997), La Plata (Nitiu, 2003), Buenos Aires (Nitiu et al., 2003) and Bahía Blanca (Murray et al., 2010). Schinus was recorded in La Plata (Nitiu, 2003) and Bahía Blanca (Murray et al., 2010) while Myrsine was registered in Caxias do Sul (Brasil) (Vergamini et al., 2006) and La Plata (Nitiu, 2003).
It must be highlighted that many important taxa recorded in this study, in particular Poaceae, Cupressaceae, Platanus, Quercus, Urticaceae, Chenopodiaceae and Ambrosia, are cited as the most aeroallergenic pollen types in Europe (Baroni et al., 2008; D'Amato et al., 2007). In addition, many of them exceeded moderate and high concentrations thresholds during considerable periods of time along the year. Grasses could be particularly important in Montevideo since they are the major cause of pollinosis in Europe (D'Amato et al., 2007) and represented up to $47 \%$ of total pollen in Montevideo. Furthermore, Poaceae pollen concentrations exceeded during weeks threshold levels indicated in other countries as responsible for triggering allergic responses in sensitive individuals (Feo Brito et al., 2011). However, the potential impact of allergenic airborne pollen in public health has not been evaluated in Uruguay and should be addressed in further investigations.

Regarding the meteorological influence on the airborne pollen, mean daily temperature showed a positive influence on pollen values, in particular, over non-woody pollen mainly due to most nonwoody plants flower during spring and summer. In addition, high temperatures, may have prompted not only anthesis, and therefore pollen emission, but, together with moderate winds and low relative humidity, also pollen dispersion (Helbig et al., 2004).

The washout effect of rainfall on pollen concentrations can be difficult to establish. This effect could explain some differences, for instance, March 2001 was rainier than other periods and rainfall could have washed out airborne pollen, bringing also the pollen season to an end. Even though, on the studied periods, rainfalls during summer were similar to the average values for the 1961-1990 period, while very low rainfalls were recorded in January 2011-12 when a a severe summer drought was experienced. This could explain the low non-woody pollen recorded in January and February 2011-12 since herbaceous vegetative growth could have been severely affected because of the drought. On the other hand, higher accumulated rainfall values previous to pollination period can have a positive effect on non-woody pollen concentration values (Cariñanos et al., 2004; McLauchlan et al., 2011). Higher rainfalls recorded weeks before February and March 2013-14 may have prompted higher non-woody pollen concentrations recorded during these months. The influence of 
meteorological conditions on pollen concentrations, previous and during the pollination periods, could be veiled by the fact that non-woody and woody categories include a wide range of species that have different climatic requirements and will be the subject of further analysis.

\section{Conclusions}

The marked seasonality observed on the pollen spectra of Montevideo city is determined by the flowering periods of the plants that are sources of most abundant pollen types, in particular, anemophilous species.

Woody pollen dominated the spectra by the end of winter and spring while non-woody pollen accounted for most of anemophilous pollen by the end of spring and summer. The most important contributor to total pollen was Poaceae, a well represented pollen type since species of this family are dominant in the local and regional vegetation.

Inter-annual differences were observed in terms of pollen concentration, and peak concentration dates. Temperature, relative humidity and accumulated rainfalls of previous weeks were the most important parameters influencing pollen concentrations.

Bivariate analysis of wind speed and direction suggest that rural areas are potential sources of pollen and have some influence on the pollen concentrations recorded in Montevideo.

Allergenic taxa were registered in high concentrations in Montevideo city, highlighting the relevance of aeropalynological studies for public health and urban planning.

This study spanned only four year and just three of them consecutive; therefore, more data are needed to evaluate inter-annual and seasonal variations, to elaborate predictive models for particular pollen taxa and to assess the influence of meteorological variables on pollen values at species level, issues that are the focus of further studies.

\section{Acknowledgments}

We acknowledge CSIC I+D (2010), PEDECIBA and ANII for their financial support. We also thank INUMET for providing the meteorological data from Carrasco Airport meteorological station.

\section{BibLIOGRAPHY}

AAAAI. 2016. NAB pollen and mold spore levels. American Academy of Allergy, Asthma \& Immunology. Available: http://pollen.aaaai.org/nab/index. $\mathrm{cfm} ? \mathrm{p}=$ reading_charts $3 \&$ statid $=85$.

ARCOS, A. \& R. POSE. 2008. Informe preliminar del censo de arbolado público. Montevideo, Intendencia Municipal de Montevideo.

ASHER, M.I., S. MONTEFORT \& B. BJORKSTEN 2006. Worldwide time trends in the prevalence of symptoms of asthma, allergic rhinoconjunctivitis, and eczema in childhood: ISAAC phases one and three repeat multicountry cross-sectional surveys. The Lancet 368: 733-743.

BARONI, M.V., D.A. ALVAREZ, G.A. WUNDERLIN \& G.A. CHIABRANDO. 2008. Analysis of IgE binding proteins of Celtis tala pollen. Food and Agricultural Immunology 19: 187-194.

BASSETT, I.J., C.W. CROMPTON \& J.A. PARMELEE. 1978. An atlas of airborne pollen grains and common fungus spores of Canada. Otawa: Department of Agriculture.

BIANCHI, M.M. 1992. Calendario polínico de la ciudad de Mar del Plata (Agosto 1987-Agosto 1989). Archivos Argentinos de Alergia Inmunología. Clínica 23: 73-86.

BIANCHI, M.M. \& S.E. OLABUENAGA. 2006. A 3-year airborne pollen and fungal spores record in San Carlos de Bariloche, Patagonia, Argentina. Aerobiologia 22: 247-257.

BRETON, M.C.,M. GARNEAU, I.FORTIER, F. GUAY \& J. LOUIS. 2006. Relationship between climate, pollen concentrations of Ambrosia and medical consultations for allergic rhinitis in Montreal, 1994-2002. Science of the Total Environment 370: 39-50.

BROWN, T., D.A. FRENZ \& T.L. WIMPSETT. 1993. Operating instructions for the Rotorod Sampler. Minnetonka: Sampling Technologies, Inc, USA.

CABRERA, A.L. \& A. WILLINK. 1973. Biogeografia de América Latina. Washington, D.C., Secretaría de la OEA.

CARIÑANOS, P., C. GALAN, P. ALCAZAR \& E. DOMINGUEZ. 2004. Airborne pollen records response to climatic conditions in arid areas of the Iberian Peninsula. Environmental and Experimental Botany 52: 11-22.

CARSLAW, D.C. 2015. The openair manual - open-source tools for analyzing air pollution data. Manual for version 1.1-4, King's College London.

CECCHI, L., T.T. MALASPINA, R. ALBERTINI, M. ZANCA, E. RIDOLO, I. USBERTI, M. MORABITO, P. DALL'AGLIO \& S. ORLANDINI. 2007. The contribution of long-distance transport to the presence of Ambrosia pollen in central northern Italy. Aerobiologia 23: 145-151. 
CECCHI, L., G. D'AMATO, J.G. AYRES, C. GALAN, F.FORASTIERE,B. FORSBERG, J. GERRITSEN, C. NUNES, H. BEHRENDT, C. AKDIS, R. DAHL \& J. ANNESI-MAESANO. 2010. Projections of the effects of climate change on allergic asthma: The contribution of aerobiology. Allergy 65: 10731081.

D'AMATO, G., L. CECCHI, S. BONINI, C. NUNES, I. ANNESI-MAESANO, H. BEHRENDT, G. LICCARDI, T. POPOV \& P. VAN CAUWENBERGE. 2007. Allergenic pollen and pollen allergy in Europe. Allergy 62: 976-990.

DAMIALIS, A., D. GIOULEKAS, C. LAZOPOULO, C. BALAFOUTIS \& D. VOKOU. 2005. Transport of airborne pollen into the city of Thessaloniki: the effects of wind direction, speed and persistence. International Journal of Biometeorology 49: 139145.

DE WEGER, L.A, K.C. BERGMANN, A. RANTIOLEHTIMÄKI, Å. DAHL, J. BUTERS, CH. DÉCHAMP, J. BELMONTE, M. THIBAUDON, L. CECCHI, J.P. BESANCENOT, C. GALÁN \& Y. WAISEL. 2013. IMPACT OF POLLEN. IN: SOFIEV M, BERGMANN K. (eds.) Allergenic Pollen. A Review of the Production, Release, Distribution and Health Impacts. Dordrecht, Springer Science+Business Media. p. 161-215

EDMONDS, R.L. 1979. Aerobiology: The Ecological Systems Approach. Straudsburg (PA), Dowden, Hutchinson and Ross.

FEO BRITO, F., P. MUR GIMENO, J. CARNÉS J, E. FERNÁdEZ CALDAS \& A.M. ALONSO, GARCIA, R. \& M. GUERRA. 2011. Grass pollen, aeroallergens and clinical symptoms in Ciudad Real, Spain. Journal of Investigational Allergology and Clinical Immunology 20: 295302.

FREI, T. \& E GASSNER. 2007. Climate change and its impact on birch pollen quantities and the start of the pollen season an example from Switzerland for the period 1969-2006. International Journal of Biometeorology 52: 667-674.

FUHRMAN, C., H. SARTER, M. THIBAUDON, M.C. DELMAS, A. ZEGHNOUN \& J. LECADET. 2007. Short-term effect of pollen exposure on antiallergic drug consumption. Annals of Allergy, Asthma \& Immunology 99: 225-231.

GALÁN, C., A. ARIATTI, M. BONINI, B. CLOT, B. CROUZY, A. DAHL, D. FERNANDEZGONZÁLEZ, G. FRENGUELLI, R. GEHRIG, S. ISARD, E. LEVETIN, D.W. LI, P. MANDRIOLI, C.A. ROGERS, M. THIBAUDON, I. SAULIENE, C. SKJOTH, M. SMITH \& M. SOFIEV. 2017. Recommended terminology for aerobiological studies. Aerobiologia, 33, 293-295.
GENTILE, D., A. BARTHOLOW, E. VALOVIRTA, G. SCADDING \& D. SKONER. 2013. Current and Future Directions in Pediatric Allergic Rhinitis. The Journal of Allergy and Clinical Immunology: In Practice 1: 214-226.

GREGORY, P.H. 1973. The Microbiology of the Atmosphere. New York, John Wiley \& Sons, Inc.

HELBIG, N., B.VOGEL, H. VOGEL \& F. FIEDLER. 2004. Numerical modelling of pollen dispersion on the regional scale. Aerobiologia 20: 3-19.

HIDALGO, P.J., C. GALÁN \& E. DOMÍNGUEZ. 1999. Pollen production of the genus Cupressus. Grana 38: 296-300.

LATORRE, F. 1997. Comparison between phenological and aerobiological patterns of some arboreal species of Mar del Plata (Argentina). Aerobiologia 13: $49-59$.

LATORRE, F. \& C. PÉREZ. 1997. One year of airborne pollen sampling in Mar del Plata (Argentina). Grana 36: 49-53.

LATORRE, F. \& M.A. CACCAVARI. 2009. Airborne pollen patterns in Mar del Plata atmosphere (Argentina) and its relationship with meteorological conditions. Aerobiologia 27: 297 312.

LEWIS, W.H., P. VINAY \& V.E. ZENGER. 1983. Airborne and allergenic pollen in North America. Baltimore, The Johns Hopkins University Press.

LOMBARDO, A. 1979. Los árboles cultivados en los paseos públicos. Montevideo, Intendencia Municipal de Montevideo.

LOMBARDO, A. 1982. Flora Montevidensis. Vol. I. Montevideo, Intendencia Municipal de Montevideo.

LOMBARDO, A. 1983. Flora Montevidensis. Vol. II Gamopétalas. Montevideo, Intendencia Municipal de Montevideo.

LOMBARDO, A. 1984. Flora Montevidensis. Vol. III Monocotiledoneas. Montevideo, Intendencia Municipal de Montevideo.

LORSCHEITTER, M.L., F. MACHADO VIEIRA \& F. DE OLIVERA. 1986. Conteúdo polínico atmosférico na cidade de Caixas do Sul, Río Grande do Sul (Brasil), e sua correlação alergógena. Paleobotanica e Palinolinologiana América do Sul, Boletin IG-USP, Instituto Geociênciencias, Universidade de São Paulo17: 131-140.

MAHURA, A.G., U.S. KORSHOLM, A.A BAKLANOV \& A. RASMUSSEN. 2007. Elevated birch pollen episodes in Denmark: Contributions from remote sources. Aerobiologia 23: 171-179.

MALLO, A.C., D.S. NITIU \& M.C. GARDELLA SAMBETH. 2011. Airborne fungal spore content in the atmosphere of the city of La Plata, Argentina. Aerobiologia 27: 77-84. 
MARKGRAF, V. \& H.L. D'ANTONI. 1978. Pollen flora of Argentina. Modern spore and pollen types of Pterydophyta, Gymnospermae and Angiospermae. Tucson, The Universtity Press.

MCLAUCHLAN, K.K., CH.S. BARNES \& J.M. CRAINE. 2011. Interannual variability of pollen productivity and transport in mid-North America from 1997 to 2009. Aerobiologia 27: 181-189.

MURRAY, M.G., M.I. SONAGLIONI \& C.B. VILLAMIL. 2002. Annual variation of airborne pollen in the city of Bahía Blanca, Argentina. Grana 41: 183-189.

MURRAY, M.G., R.L. SCOFFIELD, C. GALÁN \& C.B. VILLAMIL. 2007. Airborne pollen sampling in a Wildlife Reserve in the south of Buenos Aires province, Argentina. Aerobiologia 23: 107-117.

MURRAY, M.G., C. GALÁN \& C.B. VILLAMIL. 2008. Aeropalynological research in Salitral de la Vidriera, Buenos Aires province, Argentina. Aerobiologia 24: 181-190.

MURRAY, M.G., C. GALÁN \& C.B. VILLAMIL. 2010. Airborne pollen in Bahía Blanca, Argentina: seasonal distribution of pollen types. Aerobiologia 26: 195-207.

MURRAY, M.G \& C. GALÁN. 2016. Effect of the meteorological parameters on the Olea europaea L. pollen season in Bahía Blanca (Argentina). Aerobiologia 32:541-553.

NILSSON, S. \& S. PERSSON. 1981. Tree pollen spectra in the Stockholm region (Sweden), 1973-1980. Grana 20:179-182.

NITIU, D.S., A.C. MALLO \& E.J. ROMERO. 2003. Quantitative aeropalynology in the atmosphere of Buenos Aires city, Argentina. Aerobiologia 19: $1-10$.

NITIU, D.S. 2006. Aeropalynologic analysis of La Plata City (Argentina) during a 3-year period. Aerobiologia 22: 79-87.

NITIU, D.S \& A.C. MALLO. 2011. Seasonal variation of pollen and fungal spores in the atmosphere of Plata city (Argentina). Bol. Soc. Argent. Bot. 46: 297-304

NOETINGER, M., E.J. ROMERO \& F.D. MAJAS. 1994. Airborne pollen and spores monitoring in Buenos Aires City: A preliminary report. Part II. Herbs, weeds (NAP) and spores. General discussion. Aerobiologia 10: 129-139.

OLSON, D.M., E. DINERSTEIN, E.D. WIKRAMANAYAKE, N.D.BURGESS, G.V.N. POWELL, E.C. UNDERWOOD, J.A. D'AMICO, I. ITOUA, H.E. STRAND, J.C. MORRISON, C.J. LOUCKS, T.F. ALLNUTT, T.H. RICKETTS, Y. KURA, J.F. LAMOREUX, W.W. WETTENGEL, P. HEDAO \& K.R. KASSEM. 2001. Terrestrial ecoregions of the world: A new map of life on Earth. BioScience 51: 933-938.
PEEL, R.G., R. KENNEDY, M. SMITH \& O.HERTEL. 2014. Relative efficiencies of the Burkard 7-Day, Rotorod and Burkard Personal samplers for Poaceae and Urticaceae pollen under field Conditions. Ann. Agr. Environ. Med. 21: 745-752.

PÉREZ, C. \& M.M. PÁEZ. 1998. Seasonal airborne pollen pattern in Mar del Plata City, Argentina. Aerobiologia 14: 383-389.

PÉREZ, C.F., J.M. GARDIOL \& M.M. PÁEZ. 2001. Comparison of intradiurnal variation of airborne pollen in Mar del Plata (Argentina). Non-arboreal pollen. Aerobiologia 17: 151-163.

PÉREZ, C.F., J.M. GARDIOL \& M.M. PÁEZ. 2003. Diurnal variation of airborne pollen in Mar del Plata (Argentina). Arboreal pollen. Grana 42: 161167.

PÉREZ, C., M.I. GASSMANN, M.COVI. 2009. An evaluation of the airborne pollen-precipitation relationship with the superposed epoch method. Aerobiologia 25: 313-320.

RANTA, H., T. HOKKANEN, T. LINKOSALO, L. LAUKKANEN, K.BONDESTAM \& A. OKSANEN. 2008. Male flowering of birch: Spatial synchronization, year-to-year variation and relation of catkin numbers and airborne pollen counts. Forest Ecol. Manag. 255: 643-650.

RECIO, M., S. DOCAMPO, J. GARCÍA-SÁNCHEZ, M.M TRIGO, M. MELGAR \& B. CABEZUDO. 2010. Influence of temperature, rainfall and wind trends on grass pollination in Malaga (western Mediterranean coast). Agr. Forest Meteorol. 150: 931-940.

ROJAS, G., J.M. ROURE. 2001. Atmospheric pollen in Santiago, Chile. Grana 40: 126-132.

Soriano, A. 1992. The Río de la Plata Grasslands. In: COUPLAND RT. (ed.) Natural grasslands. Introduction and Western hemisphere. Amsterdam, Elsevier. p. 367-407.

SPIEKSMA, F.TH., G. D’AMATO, J. MULLINS, N. NOLARD, R. WACHTER \& E.R. WEEK. 1989. City spore concentrations in the European Economic Community (EEC). VI. Poaceae (Grasses) 1982-1986. Aerobiologia 5: 38-43.

TEJERA, L. \& A. BERI. 2003. Estudio palinológico de la ciudad de Montevideo, R.O.del Uruguay. Análisis preliminar. Polen 12: 107-115.

TEJERA, L. \& A. BERI. 2005. First volumetric airborne pollen sampling in Montevideo City, Uruguay. Aerobiologia 21: 33-41.

TORMO MOLINA, R., A. MUÑOZ, I. SILVA \& F. GALLARDO. 1996. Pollen production in anemophilous trees. Grana 35: 38-46.

TORO, A.R., J.A. CÓRDOBA, M. CANALES, S.R.G. MORALES, P.P. MARDONES \& G.M.A. LEIVA. 2015. Trends and thresholds exceedances analysis 
of airborne pollen concentrations in Metropolitan Santiago Chile. PLoS ONE 10(5): e0123077. doi:10.1371/journal.pone.0123077

VERGAMINI, S.M., R.M. VALENCIA-BARRERA, B.C. DE ANTONI ZOPPAS, C. PÉREZ MORALES \& D. FERNÁNDEZ-GONZÁLEZ. 2006. Pollen from tree and shrub taxa in the atmosphere of Caxias do Sul (Rio Grande do Sul, Brazil). Aerobiologia 22: 141-148.

ZIELLO, C., T.H. SPARKS, N. ESTRELLA, J. BELMONTE, K.C. BERGMAN, E. BUCHER, M.A. BRIGHETTI, A. DAMIALIS, M. DETANDT, C. GALÁN, R. GEHRIG, L. GREWLING, A.M. GUTIÚRREZ BUSTILLO, M. HALLSDÓTTIR,
M.C. KOCKHANS-BIEDA, C. DE LINARES, D. MYSZKOWSKA, A. PÀLDY, A. SÁCHEZ M. SMITH, M. THIBAUDON, A. TRAVAGLINI, A. URUSKA, R.M. VALENIA-BARRERA, D. VOKOU, R. WACHTER, L.A. DE WEGER \& A. MENZEL. 2012. Changes to Airborne Pollen Counts across Europe. PLoS ONE 7(4): http://dx.doi. org/10.1371/journal.pone.0034076

Recibido el 4 de diciembre de 2017, aceptado el 3 de abril de 2018. Editor: Gonzalo J. Márquez. 
